\title{
Understanding low COPD exacerbation rates in Japan: a review and comparison with other countries
}

This article was published in the following Dove Press journal: International Journal of COPD

\section{Takeo Ishii I,2,* \\ Masaharu Nishimura ${ }^{3, *}$ \\ Asako Akimoto' \\ Mark H James ${ }^{4}$ \\ Paul Jones ${ }^{4,5, *}$ \\ 'Respiratory Medical Affairs, Development and Medical Affairs, GSK K.K., Tokyo, Japan; ${ }^{2}$ Graduate School of Medicine, Nippon Medical School, Tokyo, Japan; ${ }^{3}$ Department of Respiratory Medicine, Faculty of Medicine and Graduate School of Medicine, Hokkaido University, Sapporo, Japan; ${ }^{4}$ Respiratory Franchise (omit Medical), GlaxoSmithKline, Brentford, Middlesex, UK; ${ }^{5}$ Institute of Infection and Immunity, St George's, University of London, London, UK}

*These authors contributed equally to this work
Correspondence: Paul Jones

Respiratory Franchise (omit Medical), GlaxoSmithKline, GSK House, 980 Great West Road, Brentford, Middlesex TW8 8GS, London, UK

Email paul.8.jones@gsk.com

\begin{abstract}
COPD is associated with significant morbidity and is one of the leading causes of death worldwide. Periods of exacerbation, the acute worsening of symptoms, are interspersed throughout the disease's natural history and can result in increased treatment burden and hospitalization for patients with COPD. The frequency of exacerbations varies between countries, with both epidemiological studies and randomized controlled trials (RCTs) showing significant differences in observed prevalence rates. Differences in study design and the healthcare setting are likely to contribute to differences in exacerbation frequency, however the perceived rate of exacerbations in Japan is currently lower then the rest of the world. This review identified nine cohort studies and five RCTs that reported COPD annual exacerbation rates in Japan in the ranges of $0.1-2.1$ and $0.33-1.79$, respectively. The difference in exacerbation rate between studies appeared greater than the difference between Japan and Western countries, likely because of disparities between settings, design, and inclusion criteria. Of these, only one (Understanding the Long-Term Impacts of Tiotropium) had uniform inclusion criteria across different regions. This study found that the annual rate of exacerbation events per patient in Japan was 0.61, compared with 0.85 worldwide in the placebo groups. This review summarizes the published rates of COPD exacerbations in Japan and the rest of the world and explores the hypotheses as to why rates in Japan might be lower than other countries. These include access to medical care, variance in the associated morbidity profile, environmental factors, diagnostic crossover with related diseases, and differences in study design (including the underreporting of COPD exacerbations in Japan). Understanding the reasons why COPD exacerbation rates appear lower in Japan could help clinicians to recognize and modify treatment behaviors, which may lead to improved patient outcomes in all populations.
\end{abstract}

Keywords: COPD, exacerbation rate, asthma-COPD overlap, Japan

\section{Introduction}

COPD is associated with significant morbidity and mortality, with 2020 estimates showing that it is likely to become the third most common cause of death worldwide. ${ }^{1}$ Impairments are present in the health status of patients with COPD of all severities, even in those with mild airway obstruction. ${ }^{1}$ The natural history of COPD is interspersed by exacerbations - the acute worsening of symptoms. ${ }^{2}$ Importantly, morbidities often manifest alongside COPD exacerbations, and they are known to have a negative impact on patients' quality of life, $\mathrm{FEV}_{1}$, the likelihood of hospitalization, readmission, health status, and disease progression. ${ }^{1,3}$ A Pan-European study of patients with COPD found that they recorded mean healthrelated quality of life (HRQL) scores that were over twice the clinically significant 
threshold for being considered "impaired" (as shown using the St George's Respiratory Questionnaire-COPD specific [SGRQ-C]), ${ }^{1}$ with those patients suffering an exacerbation having a worse SGRQ-C score compared with those with stable disease. This finding supports those from another study which demonstrated that a single nonhospitalized exacerbation can have a large and long-lasting effect on patient's health status. ${ }^{4}$

Exacerbations of COPD have a complex pathogenesis with viral or bacterial respiratory infections being the prime triggers, although pollution and climate are also known to play a role. ${ }^{3}$ Exacerbations are associated with increased inflammation of the airways, production of mucus, and the trapping of gas. ${ }^{3}$ Ultimately, COPD exacerbations are associated with significant mortality. ${ }^{3}$

Although the COPD burden is global, an analysis of the rate of exacerbations reported in both epidemiological studies and randomized controlled trials (RCTs) of patients with COPD demonstrates that it is not uniform worldwide. However, differences between studies are likely to be significantly influenced by the cohort setting (eg, primary vs secondary or tertiary care) and the specific inclusion criteria. For example, the multicenter, international, longitudinal, observational ECLIPSE study $(\mathrm{N}=2,138)$ conducted in secondary and tertiary care in North America, Europe, and New Zealand reported an annual exacerbation rate of 1.2 per patient, ${ }^{2}$ while the Salford Lung study $(\mathrm{N}=2,799)$, an RCT of fluticasone furoate-vilanterol for COPD conducted in primary care in the UK, reported an exacerbation rate of 2.0 in the 12 months prior to randomization. ${ }^{5}$ Further variation can be seen in the DACCORD study (an ongoing real-world, noninterventional, community-based study in Germany $[\mathrm{N}=3,974]$ ), which reported an annual COPD exacerbation rate of just 0.4 during the first year of follow-up. ${ }^{6}$

In contrast to observed Pan-European and North American exacerbation rates, COPD exacerbations appear to be generally less frequent in Japan compared with the rest of the world. ${ }^{7}$ Notably, there are currently no studies that are directly comparable in design or inclusion criteria between Japan and the rest of the world. However, the UPLIFT trial, which was a multicenter study $(\mathrm{N}=5,992)$ of tiotropium use in 30 countries in patients with $\mathrm{COPD},{ }^{8}$ included patients from Japan. A subgroup analysis of patients enrolled to the control arm in the UPLIFT trial showed that the exacerbation rate in the Japanese cohort $(\mathrm{n}=100)$ was lower than both the Asian and the overall study cohorts (mean number of exacerbations per patient year was 0.61 [Japanese cohort] compared with 0.92 [Asian cohort] and 0.85 [total UPLIFT cohort]). ${ }^{7}$
Understanding the differences in exacerbation rates between Japan and other regions of the world may elucidate factors that are important for the effective management of patients with COPD. The aim of this review is to discuss the frequency of, and the potential factors affecting, COPD exacerbations in Japan compared with other Asian and Western countries.

\section{Literature search and review methodology}

During the literature review and article selection, we used PubMed searches to identify original research articles that were published up to May 15, 2017, using the search terms “COPD” AND "Japan" AND "exacerbation". Overall, 161 papers were initially identified; screening of the titles and abstracts for relevance identified 50 papers of interest.

A further screening of the full text of these 50 papers identified a total of 14 studies which met the following criteria and are discussed in this review: 1) studies that recruited Japanese patients and for which the incidence of exacerbations as a rate per person per year for the Japanese population living in Japan was available and 2) studies for which the incidence of exacerbations in a Japanese population was available from an unpublished source (one study, COSMOS-J). ${ }^{9}$ For studies that had multiple associated papers, the paper with the most recent data, patients with more general COPD, and data on Global initiative for chronic Obstructive Lung Disease (GOLD) stage was chosen (in order of priority).

Overall, the search identified 9 COPD ${ }^{10-18}$ cohort studies and 5 pharmaceutical company-sponsored RCTs. ${ }^{7,919-21}$ As there can be some significant differences in population characteristics between cohort studies and RCTs, findings from these two study types are summarized separately.

\section{Reported COPD exacerbation rates in Japan Cohort studies}

Overall, nine cohort studies reported exacerbation rates in patients with COPD in Japan (Table 1). A summary of the study characteristics, key inclusion criteria and patient demographics, definitions of COPD exacerbation, and incidence of exacerbations (a rate per person per year) is presented in Table 1 . The study design, study center, recruitment period, inclusion criteria, and detailed definition of COPD exacerbation are shown in Table S1, but the number of patients is only shown in Table $1 . .^{10-18}$ 
Table I Summary of exacerbation rates and key patient characteristics from cohort studies detailing COPD exacerbation rates in Japan ${ }^{10-18}$

\begin{tabular}{|c|c|c|c|c|c|c|c|c|}
\hline \multirow{2}{*}{$\begin{array}{l}\text { Cohort } \\
\text { (study) }\end{array}$} & \multirow{2}{*}{$\begin{array}{l}\text { Inclusion } \\
\text { criteria }\end{array}$} & \multirow{2}{*}{$\begin{array}{l}\text { Definition } \\
\text { of COPD } \\
\text { exacerbation }\end{array}$} & \multirow[t]{2}{*}{$\mathbf{N}$} & \multicolumn{4}{|c|}{ Patient baseline characteristics } & \multirow{2}{*}{$\begin{array}{l}\text { Incidence of } \\
\text { exacerbations } \\
\text { (per person } \\
\text { per year) }^{a}\end{array}$} \\
\hline & & & & $\begin{array}{l}\text { Age } \\
\text { (years) }^{a}\end{array}$ & $\begin{array}{l}\text { Female } \\
\text { (\%) }\end{array}$ & $\begin{array}{l}\text { GOLD } \\
\text { stage III/IV } \\
(\%)\end{array}$ & $\begin{array}{l}\text { ICS use } \\
(\%)\end{array}$ & \\
\hline $\begin{array}{l}\text { Kyoto cohort } \\
(\text { Takahashi et al, 20I2) }\end{array}$ & $\begin{array}{l}\text { - Male patients with COPD } \\
\text { - No exacerbation history } \\
\text { criteria }\end{array}$ & $\begin{array}{l}\text { Symptom-based } \\
\text { (diary) }\end{array}$ & 93 & 73 & 0 & $30 / 5$ & 40.8 & $0.8,1.2^{\mathrm{b}}$ \\
\hline $\begin{array}{l}\text { Nippon cohort } \\
(\text { Motegi et al, 2013) } 12\end{array}$ & $\begin{array}{l}\text { - Patients with COPD } \\
\text { (GOLD) } \\
\text { - } \geq 40 \text { years of age } \\
\text { - Current or ex-smokers } \\
\text { ( } \geq 20 \text { pack-years) } \\
\text { - No exacerbation history } \\
\text { criteria }\end{array}$ & $\begin{array}{l}\text { Symptom-based } \\
\text { (diary) }\end{array}$ & 183 & $71.4 \pm 8.7$ & 7.1 & $33.9 / 9.8$ & NR & 0.57 \\
\hline $\begin{array}{l}\text { Kitano cohort } \\
(\text { Takemura et al, 2013) }\end{array}$ & $\begin{array}{l}\text { - Patients with COPD } \\
\text { (GOLD) } \\
\text { - Current or ex-smokers } \\
\text { ( } \geq 10 \text { pack-years) } \\
\text { - No change in medication } \\
\text { for } 3 \text { months before study } \\
\text { - No exacerbation history } \\
\text { criteria }\end{array}$ & $\begin{array}{l}\text { Event-based } \\
\text { (medical } \\
\text { records) }\end{array}$ & 55 & $69 \pm 8$ & 27.3 & $16.4 / 5.4$ & 100 & 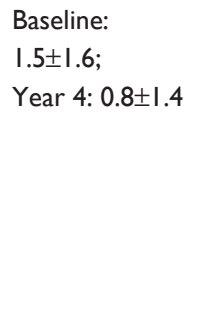 \\
\hline $\begin{array}{l}\text { Hokkaido cohort } \\
(\text { Suzuki et al, 2014) }\end{array}$ & $\begin{array}{l}\text { - Patients with COPD } \\
\text { (GOLD) } \\
\text { - } \geq 40 \text { years of age } \\
\text { - Current or ex-smokers } \\
\text { ( } \geq 10 \text { pack-years) } \\
\text { - No exacerbation I month } \\
\text { prior to study }\end{array}$ & $\begin{array}{l}\text { Symptom-based } \\
\text { and event- } \\
\text { based }\end{array}$ & 268 & $70 \pm 8$ & 6 & $24.3 / 4.9$ & NR & $\begin{array}{l}0.78 \pm 1.16,^{c} \\
0.24 \pm 0.47,^{c} \\
0.20 \pm 0.43,^{c} \\
0.13 \pm 0.28,^{c} \\
0.06 \pm 0.19^{c}\end{array}$ \\
\hline $\begin{array}{l}\text { Saitama cohort } \\
(\text { Kurashima et al, 2015) } 10\end{array}$ & $\begin{array}{l}\text { - Male patients with COPD } \\
\text { - No exacerbation history } \\
\text { criteria }\end{array}$ & Event-based & 65 & $70.8 \pm 6.4$ & 0 & NR & 50.8 & $0.67 \pm 0.85$ \\
\hline $\begin{array}{l}\text { CAP study } \\
\text { (Matsunaga et al, 20I5)"' }\end{array}$ & $\begin{array}{l}\text { - Clinical diagnosis of } \\
\text { COPD } \\
\text { - } 40-95 \text { years of age } \\
\text { - No exacerbation in the } \\
4 \text { weeks prior to the } \\
\text { survey }\end{array}$ & Event-based & 1,168 & $72.1 \pm 8.3$ & 11.4 & $26.0 / 7.7$ & 6.8 & $0.53 \pm 0.87$ \\
\hline $\begin{array}{l}\text { Kurume cohort (Natori } \\
\text { et al, 2016) }\end{array}$ & $\begin{array}{l}\text { - Patients with COPD } \\
\text { (GOLD) } \\
\text { - No exacerbation } 4 \text { weeks } \\
\text { prior to study entry }\end{array}$ & Symptom-based & 123 & $\begin{array}{l}64.3 \\
67.8 \\
68.5 \\
70.4^{c}\end{array}$ & $\begin{array}{l}20.7 \\
10.5 \\
14.3 \\
0^{c}\end{array}$ & $22.8 / 7.3$ & $\begin{array}{l}3.5 \\
15.8 \\
25.0 \\
11.1^{d}\end{array}$ & $\begin{array}{l}0.1 \pm 0.2,0.9 \pm 0.1 \\
1.4 \pm 0.2,2.1 \pm 0.4^{d}\end{array}$ \\
\hline $\begin{array}{l}\text { Keio cohort (Sato et al, } \\
2016)^{14}\end{array}$ & $\begin{array}{l}\text { - Patients with COPD } \\
\text { (spirometry) } \\
\text { - No exacerbation } \\
\text { for } \geq \text { I month prior } \\
\text { to enrollment }\end{array}$ & Event-based & 311 & $72.6 \pm 8.1$ & 6.8 & $23.2 / 5.8$ & $\begin{array}{l}26.6 \\
32.8 \\
47.2^{\mathrm{e}}\end{array}$ & $0.28^{f}$ \\
\hline $\begin{array}{l}\text { Chiba cohort } \\
(\text { Takayanagi et al, } \\
2017)^{17}\end{array}$ & $\begin{array}{l}\text { - Patients with COPD } \\
\text { (ATS/ERS) } \\
\text { - Current or ex-smokers } \\
\text { - No exacerbation history } \\
\text { criteria }\end{array}$ & Event-based & 58 & $69.7 \pm 7.3$ & 12.1 & $15.5 / 6.9$ & NR & $\begin{array}{l}0.75 \\
(1.5 \pm 0.9 / 2 \text { years })^{g}\end{array}$ \\
\hline
\end{tabular}

Notes: a Data are presented as mean \pm SD (where available) unless otherwise stated; bdata represent patients with high lgG (0.8 events/year) and normal lgG (I.2 events/ year); 'data represent symptom-based due to subjective complaints $(0.78 \pm 1.16)$, symptom-based by strict definition, confirmed by CRC ( $0.24 \pm 0.47)$, event-based due to requiring prescription change $(0.20 \pm 0.43)$, event-based due to requiring antibiotic treatment $(0.13 \pm 0.28)$, and event-based due to requiring hospital admission ( $0.06 \pm 0.19)$; ${ }^{d}$ data represent GOLD stages I-IV; e data represent nonexacerbators, mild exacerbators, and moderate/severe exacerbators; ${ }^{f}$ moderate or severe exacerbations; ${ }^{\circ}$ one-year data calculated from 2-year data.

Abbreviations: ATS/ERS, American Thoracic Society/European Respiratory Society recommendations; CRC, Clinical Research Coordinator; GOLD, Global initiative for chronic Obstructive Lung Disease; GORD, gastro-esophageal reflux disease; ICS, inhaled corticosteroid; NR, not reported. 
Across all nine cohort studies, exacerbation rates ranged 0.1-2.1 exacerbations per patient-year (Table 1) ${ }^{10-18}$ In general, COPD severity appeared to account for much of the variability, with exacerbation rates varying according to GOLD classification and modified Medical Research Council grade. ${ }^{11,13}$ For studies that assessed the whole COPD population, without respect to COPD severity, exacerbation rates ranged $0.24-0.8$ events per year. ${ }^{10,12,14,15,17,18}$ Interestingly, in the Kitano cohort study, which aimed to improve inhaler technique and adherence, exacerbation rates decreased from 1.5 at baseline to 0.8 by Year $4 .{ }^{18}$ In studies whose inclusion criteria specified no exacerbations in the 4-6 weeks prior to study entry, exacerbation rates were 0.24 and 0.28 events per person per year. ${ }^{14,15}$ Overall, when assessing the whole COPD population, it appears that exacerbation rates in Japan are lower than those seen in the ECLIPSE study (1.2 events per year) ${ }^{2}$ and a large database cohort study of primary care patients in the UK ( 0.9 events per year). ${ }^{22}$ However, the difference in exacerbation rate between studies appeared greater than the difference between Japan and Western countries, likely because of disparities between settings, design, and inclusion criteria.

\section{Randomized controlled trails}

A summary of exacerbation rates in the five identified RCTs that enrolled patients in Japan is presented in Table 2. The study design, study center, recruitment period, inclusion criteria, and detailed definition of COPD exacerbation are shown in Table S2. The number of patients is only shown in Table 2. ${ }^{7,9,19-21}$ Overall, the reported COPD exacerbation rates were $0.33-1.79 .^{7,9,19-21}$ Intra- and interstudy variations in COPD exacerbation rates occurred depending on treatment drug vs placebo, and the studies differed in inclusion and exclusion criteria, with two of the five studies excluding patients with prior exacerbation history 1 week $^{19}$ and 4 weeks ${ }^{7}$ before enrollment. The subgroup analysis performed on the UPLIFT study population shows that exacerbation rates in the placebo group and the treatment group were lower for the Japanese subgroup ( 0.61 and 0.37 per patient-year) compared with the Asian ( 0.92 and 0.68 per patient-year) and overall ( 0.85 and 0.73 per patient-year) populations (Figure $1 \mathrm{~A}){ }^{7}$ As UPLIFT has the same inclusion criteria across the different populations, this is currently the best evidence available that can provide a comparison between the Japanese population and those of other countries.

\section{Patient characteristics affecting exacerbation frequency}

Difference in exacerbation frequency might be affected by population characteristics (eg, GOLD severity, body mass index
[BMI], and age). In terms of GOLD severity, across multiple cohort studies and RCTs, it appears that patients from Japan have less severe COPD than patients from other countries. For example, $0 \%-9.8 \%$ of patients had very severe COPD in studies from Japan ${ }^{7,9,19-21}$ compared with $12 \%$ (GOLD stage IV) in the Asian cohort of the UPLIFT trial and 9\% in the total cohort. ${ }^{7}$

Across four cohort studies reporting HRQL life outcomes in Japan, SGRQ total scores varied from 23.8 to $40.6 .^{14,15,18,23}$ Data from the UPLIFT study suggested that patients from Japan have better health status compared with the rest of the world (SGRQ total score at baseline: 40.5 vs 45.9 , respectively) and other Asian countries ( $40.5 \mathrm{vs} 44.4$, respectively). ${ }^{7}$ This is despite the observation that patients from Japan tended to be older and have lower BMI compared with Western counterparts. In the cohort studies and RCTs reported here, the mean age of Japanese patients was 64-75 years (Tables 1 and 2) which is comparable but a little lower than Western patients (64-67 years), but BMI was clearly lower at $19-24 \mathrm{~kg} / \mathrm{m}^{2}$ compared to $26-28 \mathrm{~kg} / \mathrm{m}^{2}$ among Western patients. ${ }^{2,7,12-14,17}$ in ECLIPSE, Salford Lung study, DACCORD, and UPLIFT, , 2,5-7 Older age and lower BMI have been shown to be associated with poorer prognosis in COPD. . $^{1524,25}$

In summary, reported COPD exacerbation rates might be lower in Japan than other Asian countries and the rest of the world. Moreover, in general, COPD severity is reduced, and health status scores are slightly less impaired in Japan compared with other Asian and Western countries; these could be factors linked to the lower reported frequency of exacerbation.

\section{Potential factors affecting the rate of COPD exacerbations in Japan} Intrinsic and extrinsic factors

Many contributory factors may influence the low reported COPD exacerbation rate in Japan. To best understand the potential reasons for the observed differences, we must consider hypotheses relating to both intrinsic and extrinsic factors that could act upon the Japanese population in a different manner to other countries.

Intrinsic factors in this case relate to variables that are specific to the people of Japan, namely the genetic profile and ethnicity of the population. To our knowledge, no data linking genetic factors unique to the Japanese population and COPD exacerbations have been identified. Furthermore, we would suggest that intrinsic factors are unlikely to account for the difference in COPD exacerbation rate since, in the UPLIFT study, countries with populations that are of predominantly Asian ethnicity (eg, Singapore and Taiwan) all had observed trends in exacerbation rates that were different 
Table 2 Summary of exacerbation rates and key patient characteristics from RCTs detailing COPD exacerbation rates in Japan ${ }^{7,9,19-21}$

\begin{tabular}{|c|c|c|c|c|c|c|c|c|c|}
\hline \multirow[t]{2}{*}{ Study } & \multirow{2}{*}{$\begin{array}{l}\text { Inclusion criteria } \\
\text { relating to disease } \\
\text { severity and } \\
\text { exacerbation history }\end{array}$} & \multirow{2}{*}{$\begin{array}{l}\text { Definition } \\
\text { of COPD } \\
\text { exacerbation }\end{array}$} & \multirow[t]{2}{*}{ Interventions } & \multirow[t]{2}{*}{$\mathbf{N}$} & \multicolumn{4}{|c|}{ Patient baseline characteristics } & \multirow{2}{*}{$\begin{array}{l}\text { Incidence of } \\
\text { exacerbations } \\
\text { (per person }^{\text {per year) }}\end{array}$} \\
\hline & & & & & $\begin{array}{l}\text { Age } \\
\text { (years) }^{a}\end{array}$ & $\begin{array}{l}\text { Female } \\
(\%)\end{array}$ & $\begin{array}{l}\text { GOLD } \\
\text { stage III/IV (\%) }\end{array}$ & $\begin{array}{l}\text { ICS use } \\
(\%)\end{array}$ & \\
\hline $\begin{array}{l}\text { Furumoto } \\
\text { et al } \\
(2008)^{20}\end{array}$ & $\begin{array}{l}\text { Patients with chronic } \\
\text { lung disease including } \\
\text { COPD, with sequelae of } \\
\text { pulmonary tuberculosis } \\
\text { - Previous exacerbations }\end{array}$ & $\begin{array}{l}\text { Symptom- } \\
\text { based }\end{array}$ & $\begin{array}{l}\text { PV+IV } \\
\text { IV alone }\end{array}$ & $\begin{array}{l}87 \\
80\end{array}$ & $69.0 \pm 9.0$ & 36.5 & NR & NR & $\begin{array}{l}0.53 \text { (COPD } \\
\text { population; } \\
n=55)\end{array}$ \\
\hline $\begin{array}{l}\text { Sasaki et al } \\
(2009)^{21}\end{array}$ & $\begin{array}{l}\text { - Patients with COPD } \\
\text { - No exacerbation } \\
\text { criteria for inclusion or } \\
\text { exclusion }\end{array}$ & $\begin{array}{l}\text { Symptom- } \\
\text { based }\end{array}$ & $\begin{array}{l}\text { Lansoprazole } \\
15 \mathrm{mg} / \text { day } \\
\text { Placebo }\end{array}$ & $\begin{array}{l}50 \\
50\end{array}$ & $\begin{array}{l}74.9 \pm 8.9 \\
74.8 \pm 7.5\end{array}$ & 6 & $\begin{array}{l}34 / 6 \\
40 / 2\end{array}$ & $\begin{array}{l}26.0 \\
24.0\end{array}$ & $\begin{array}{l}0.34 \pm 0.72 \\
\text { I. } 18 \pm 1.4\end{array}$ \\
\hline $\begin{array}{l}\text { Fukuchi et al } \\
(201 \mathrm{I})^{7}\end{array}$ & $\begin{array}{l}\text { - Patients with COPD } \\
\text { - Post-FEV } \% \text { pred: } \leq 70 \% \\
\text { - } \text { Post-FEV } 1 / F V C: \leq 70 \% \\
\text { - } \text { No exacerbation } \\
4 \text { weeks before } \\
\text { screening }\end{array}$ & $\begin{array}{l}\text { Symptom- } \\
\text { based }\end{array}$ & $\begin{array}{l}\text { TIO } \\
\text { Placebo }\end{array}$ & 50 & $\begin{array}{l}66.9 \pm 6.0 \\
68.0 \pm 5.5\end{array}$ & 8 & $\begin{array}{l}48 / 6 \\
56 / 0\end{array}$ & $\begin{array}{l}26.0 \\
24.0\end{array}$ & $\begin{array}{l}0.37 \text { (95\% Cl: } \\
0.26-0.5 \mathrm{I}) \\
0.6 \mathrm{I}(95 \% \mathrm{Cl}: \\
0.46-0.8 \mathrm{I})\end{array}$ \\
\hline $\begin{array}{l}\text { Fukuchi et al } \\
(2016)^{19}\end{array}$ & $\begin{array}{l}\text { - Patients with COPD } \\
\text { - Post-FEV, } \% \text { pred: }<80 \% \\
\text { - Post-FEV } / \text { FVC: }<70 \% \\
\text { - } \geq 1 \text { exacerbations in the } \\
\text { previous year } \\
\text { - No exacerbation } \\
7 \text { days prior to drug } \\
\text { administration }\end{array}$ & $\begin{array}{l}\text { Symptom- } \\
\text { based }\end{array}$ & $\begin{array}{l}\text { Lysozyme } \\
270 \mathrm{mg} / \text { day } \\
\text { Placebo }\end{array}$ & 202 & $68.8 \pm 9.3$ & $\begin{array}{l}9.4 \\
8.8\end{array}$ & $\begin{array}{l}36.1 / 5.0 \\
29.4 / 5.4\end{array}$ & 8.4 & $\begin{array}{l}1.4 \pm 1.5 \\
1.2 \pm 1.4\end{array}$ \\
\hline $\begin{array}{l}\text { Jones et al } \\
(2016)^{9}\end{array}$ & - Patients with COPD & $\begin{array}{l}\text { Event-based, } \\
\text { symptom- } \\
\text { based }\end{array}$ & $\begin{array}{l}\text { FP/SAL } \\
\text { TIO }\end{array}$ & 405 & $68.3 \pm 7.0$ & 5 & NR & NR & $\begin{array}{l}\text { I.79 (95\% Cl: } \\
\text { I.56-2.05) } \\
\text { (EXACT criteria) } \\
0.33(0.24-0.44) \\
\text { (physician } \\
\text { reported) }\end{array}$ \\
\hline
\end{tabular}

Notes: aData are presented as mean \pm SD unless otherwise stated. TIO, tiotropium I8 $\mu \mathrm{g}$ once daily.

Abbreviations: EXACT, Exacerbations of Chronic Pulmonary Disease Tool; FP/SAL, fluticasone propionate/salmeterol 250/50 $\mu \mathrm{g}$ twice daily; GOLD, Global initiative for chronic Obstructive Lung Disease; ICS, inhaled corticosteroid; IV, influenza vaccine; pred, predicted; PV, pneumococcal vaccine; RCT, randomized controlled trial.

from that of Japan. ${ }^{7}$ Another intrinsic factor may be behavioral characteristics, with Japanese patients less likely to report worsening symptoms on health status questionnaires; however, this is an observational hypothesis with no scientific evidence. The lower SGRQ score (40.5 \pm 13.6 in Japanese

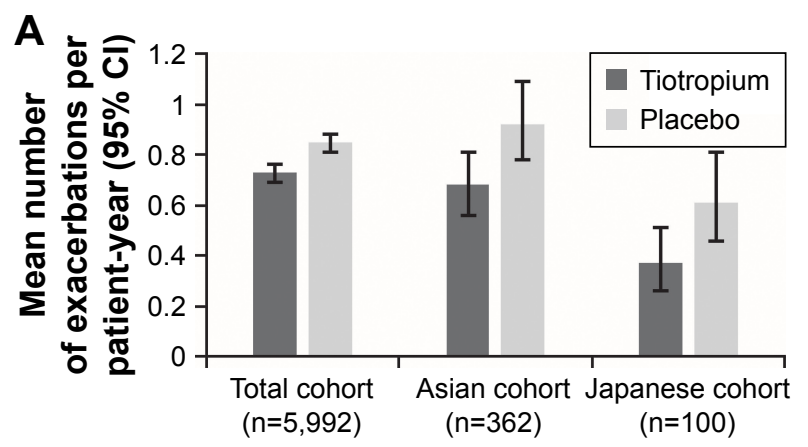

Figure I Exacerbations in the (A) UPLIFT study ${ }^{7}$ and (B) ACCESS study. ${ }^{30}$ Abbreviation: CVD, cardiovascular disease. vs $45.9 \pm 17.1$ in overall populations), in the UPLIFT study, regardless of their similar $\mathrm{FEV}_{1}$ (\% predicted) $(38.6 \pm 11.5$ in Japanese vs $39.4 \pm 12.0$ in overall populations), might reflect that kind of behavioral characteristics in Japanese. We must also be mindful that a small risk exists for these data to be

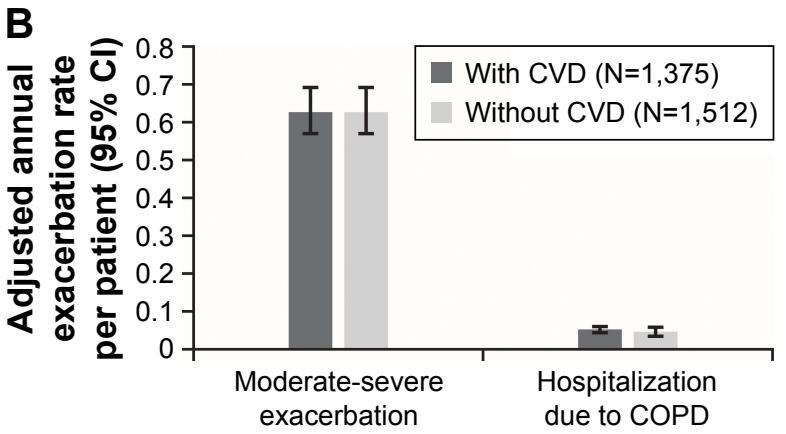


confounded by a minority of patients who overreport their symptoms, some instances of which have been reported in Japanese studies. ${ }^{15}$

Multiple extrinsic factors are potentially involved in explaining the lower exacerbation rate in Japan. In this context, these specifically relate to medical and environmental variables that are measurably different in Japan compared with other populations. Some of these key factors are outlined below, alongside our hypotheses as to how these might influence the reported exacerbation rate.

\section{Access to medical care}

The intensity of medical care generally relates to physician visit frequency. On average, Japan has nearly twice that of the Organization for Economic Co-operation and Development (OECD) average physician consultations and over three times as many as Sweden (12.9 consultations per capita vs 6.6 and 2.9 , respectively). ${ }^{26}$ This could explain, in part, the low rate of hospital admissions for COPD in Japan compared with other Asian and western countries. ${ }^{26}$ In 2013 , there was a 17-fold difference in age-sex standardized hospital admission rates for COPD across the 35 OECD countries, with Japan having the lowest rates ( $20-25$ per 100,000 population), compared with Hungary and Ireland who had the highest rates ( 350-400 per 100,000 population). ${ }^{27}$ Another explanation for the low admission rate is the diagnosis of bacterial exacerbations as pneumonia, leading to earlier treatment with antibiotics and preventing the need for hospitalization. These diagnoses might be higher in Japan than in other countries.

The studies identified in this review show clear differences in the characteristics of the Japanese COPD patient population and that of Western populations; in general, Japanese patients with COPD have lower SGRQ and COPD assessment test scores, have lower modified Medical Research Council scores, are older, have lower BMI, and majority are male., ${ }^{2,5-7}$ Several of these variables can be influenced by effective and regular physician monitoring of the condition. The reduced exacerbation rate in Japan may be a result of closer management of the patient, resulting in increased disease stability. In this respect, Japan appears to some to be leading the world in effective COPD management. Longitudinal changes in the SGRQ scores during the 5-year Hokkaido COPD cohort study $(\mathrm{N}=261)$ showed that some patients had sustained improvement in symptoms over time. ${ }^{28,29}$ Hence, there may have been a change in the natural history of COPD in Japan during the last decade, with fewer patients showing a progressive decline; this may have been impacted by the introduction of effective inhaled therapies over this period.
We should note that the lower COPD exacerbation rate reported in Japan is similar to that seen in the German population (DACCORD study). ${ }^{6}$ However, the baseline demographics in each study population, such as age, BMI, and gender, were different and the similar exacerbation rates cannot be easily attributed to an obvious variable. Therefore, similarities may exist in extrinsic factors affecting the two country populations and should be investigated further. Currently, there are no studies in a Japanese population that have inclusion criteria similar to DACCORD, and as such a comparison of these rates with other studies in Japan is not appropriate. The primary care-based ACCESS study in European patients with COPD, with and without cardiovascular disease (CVD), reported an acute exacerbation rate of 0.63 per patient per year (Figure 1B). ${ }^{30}$ This is similar to the exacerbation rate reported for the Japanese cohort in the UPLIFT study (0.61 per patient per year). ${ }^{7}$ However, it should again be noted that baseline characteristics of the two study populations were different: patients in ACCESS had a mean age of 66.1 years, mean BMI $27.2 \mathrm{~kg} / \mathrm{m}^{2}, 70 \%$ were male, $26.6 \%$ were GOLD stage III, and $6.3 \%$ were GOLD stage IV, ${ }^{30}$ while those in the Japanese cohort of UPLIFT had a mean age of 68.0 years, mean BMI $20.7 \mathrm{~kg} / \mathrm{m}^{2}, 96 \%$ were male, $56 \%$ were GOLD stage III, and none were GOLD stage IV. ${ }^{7}$

There is also the potential that regular access to medical care can influence the behavior of patients in Japan experiencing a mild exacerbation. We suggest that the reporting of a COPD exacerbation requires three things: first, that the patient recognizes the significance of the deterioration in their condition; second, that the patient reports this to their physician; and finally, that the physician makes the correct diagnosis of COPD and COPD exacerbation. As they know they have a regular scheduled physician visit coming up soon, it is possible that following an exacerbation, patients in Japan may be more likely to wait rather than seek immediate treatment, to see if their symptoms resolve spontaneously, resulting in underreporting of COPD exacerbations. This hesitancy to seek treatment may be compounded by the fact that the severity of COPD in Japanese patients is lower on average.

\section{Associated morbidities}

It is possible that a lower level of associated respiratory comorbidities in Japan may be a factor that contributes to lower COPD exacerbation rates. For example, the use of home-based long-term oxygen therapy (LTOT) for COPD has not increased in Japan (2005, 48\% of all LTOT; 2010, 
$45 \%$ of all LTOT), ${ }^{31}$ which potentially may reflect a reduction in COPD severity.

As already highlighted, there is a trend for patients with COPD in Japan to be older than those in other countries. ${ }^{7}$ But despite the aging population, data from the Japanese Ministry of Health and Welfare demonstrate that the COPD mortality rate has decreased steadily from a 1995 peak of 13.2 men and 4.7 women per 100,000, 9.7 and 2.5, respectively, in $2015 .^{32}$ This tendency is particularly noticeable in the age-adjusted mortality rate using the 1985 model population as the standard population (from a 1995 peak of 11.6 men and 2.4 women per 100,000, 3.5 and 0.6). ${ }^{33}$ Moreover, the percentage of COPD mortality among people $>80$ years of age within total COPD mortality is $>70 \%$ and increasing year-on-year, indicating that the Japanese population is living longer with more stable disease. Mortality rates are also lower in Japan $(6.0 \%-8.0 \%)$ when directly compared with the overall UPLIFT study population $(12.8 \%-13.7 \%)$ as well as the Asian subpopulation (15.8\%-21.9\%). ${ }^{7}$ This reduction in COPD mortality rate in Japan is associated with a corresponding reduction $(>40 \%)$ in disability-adjusted life years (DALYs), indicating that much of the burden of COPD is either preventable or treatable with affordable interventions. ${ }^{34}$

\section{Environmental factors hypothesis}

Ambient air pollution contributes substantially to the global burden of disease, compared with the global air pollution, air particle mass in Japan is much lower, ${ }^{35}$ which may play a role in the reduced frequency of COPD exacerbation. A decreasing trend in adult smoking rate might also affect the COPD exacerbation rate. In 1989, the adult smoking rate was $55.3 \%$ of Japanese men and $9.4 \%$ of Japanese women. Those rates gradually decreased to $32.1 \%$ and $8.5 \%$ by $2014 .{ }^{36}$ In addition, the current smoker rate in clinical studies tends to be lower compared with other countries. In the UPLIFT study, only $19.0 \%$ of Japanese patients were current smokers, compared with $29.6 \%$ of patients in overall populations. ${ }^{7}$ This might suggest that Japanese COPD patients are more likely to stop smoking on the advice of their doctors after their diagnosis. Moreover, the national diet of a country is well characterized as being influential over the health profile of its citizens. To that point, a recent meta-analysis $(\mathrm{N}=81,720)$ of a prudent Japanese diet characterized by high intake of vegetables, fruit, soy products, potatoes, seaweed, mushrooms, and fish was significantly associated with a reduced risk of both allcause and CVD mortality. ${ }^{37}$ A Westernized Japanese diet, more prevalent in the population since the 1970 s, consisting of an increased intake of meat, processed meat, bread, and dairy products, was also inversely associated with risk of all-cause, cancer, and CVD mortality. ${ }^{37}$

\section{COPD diagnosis}

It is important to note that current Global Initiative for Asthma guidelines highlight that distinguishing COPD and asthma can be problematic due to patients presenting with the clinical features of both conditions. ${ }^{38}$ Importantly, asthmaCOPD overlap (ACO) does not represent a single disease entity, ${ }^{38}$ and patients can have asthma with COPD and vice versa. Although initial recognition of ACO can be made in primary care settings, referral for diagnostic confirmation should be made as patient outcomes are often worse than for asthma or COPD alone. ${ }^{38}$

Importantly, these evolving guidelines and prescribing practices for the management of COPD and asthma may contribute to lower reports of exacerbation rates in Japan, owing to diagnostic transfer of patients. In the UPLIFT study, only $25.0 \%$ of Japanese patients were receiving inhaled corticosteroids at baseline, compared with $61.6 \%$ and $61.7 \%$ of patients in the Asian and overall populations, respectively. ${ }^{7}$ This potentially reflects the likelihood for sharp distinctions in the diagnoses between asthma and COPD in Japan, removing those patients with overlapping and more serious symptoms from Japanese study cohorts. This is important because patients with ACO are more likely to have exacerbations than patients with a predominantly emphysema phenotype alone. ${ }^{39}$

Another possibility is that, because Japanese physicians utilize computed tomography scans for the diagnosis of COPD, they actively look for the presence of emphysema. In the absence of emphysema, but in the presence of air flow limitation, Japanese physicians would likely make a diagnosis of asthma, thereby meeting one of the exclusion criteria for COPD studies. As such, Japanese studies are potentially reflective of more homogenous, emphysema-dominant patient populations with less complex and severe disease.

However, recent studies confound this conclusion. Cohort data from the USA have shown that patients with asthmaCOPD have worse outcomes than patients with COPD but without asthma, ${ }^{39}$ but a 10 -year follow-up of the Hokkaido cohort suggests a different picture. ${ }^{40}$ The Hokkaido cohort included 268 patients with COPD and a clinical opinion (by a respiratory specialist) of not having asthma. ${ }^{15,40}$ However, in a retrospective analysis of the Hokkaido cohort, ${ }^{40} 133$ (50\%) patients had the presence of asthma-like features confirmed (blood eosinophil counts $\geq 300$ cells $/ \mu \mathrm{L}$, bronchodilator 
reversibility, or atopy). However, it has to be recognized that asthma was excluded in these patients using markers that are not only specific to asthma but also seen in COPD. ${ }^{39}$

\section{Study design: reporting of COPD exacerbations varies between countries}

Ultimately, considerations relating to study design and COPD diagnosis highlight an important point relating to the chosen algorithm used to collect and report COPD exacerbations, and how this is likely to impact upon the reported rates. In the UK-based Salford Lung study, which reported an exacerbation rate higher than most previous studies, inclusion criteria were more reflective of daily clinical practice than many cohort studies and RCTs in patients with COPD. However, the reported exacerbation rates were still higher than the DACCORD study, even though both studies are putatively reflective of primary care populations in European countries. In the Salford Lung study, unlike all other studies, patients were not involved in the diagnosis of exacerbations, rather, passive data collection based on the markers of antibiotics and corticosteroid prescription was used. ${ }^{5}$ The consequence of this may have been increased diagnosis rates compared with other studies, as in the vast majority of studies exacerbations are reported using patient recall, which may introduce a recall bias in that patients would underreport events.

\section{Are there unreported exacerbations or underdiagnosed COPD in Japan?}

Underreporting of symptoms is a recognized problem, ${ }^{3}$ which is important since it is associated with a worse quality of life and an increased likelihood of hospitalization consequent to an exacerbation. ${ }^{41}$ The Phase III study ATTAIN prospectively characterized the levels and impact of reported and unreported exacerbations, comparing the rates obtained using a patient diary (Exacerbations of Chronic Pulmonary Disease Tool $\left[\mathrm{EXACT}^{\circledR}\right]$ : a 14-item electronic daily diary completed at night) vs an analysis of healthcare resource utilization (HCRU) records (including patient diary cards, prescription, and hospitalization data). ${ }^{42}$ The concordance between EXACT-identified events and HCRU-identified events was poor, with EXACT-identified exacerbation rates double that of HCRU-identified events. Moreover, irrespective of the method of detection, the rates of reported vs unreported events showed a large variation between the different countries included in the trial. ${ }^{42}$ The results of this study and others have demonstrated that there is poor agreement between diary card-reported exacerbations and those identified by medical intervention. ${ }^{42,43}$ Potential underreporting of COPD exacerbations could be a factor in the reduced exacerbation rates seen in Japan, given the method of data collection used to identify exacerbation events.

COPD is also frequently underdiagnosed in the Western world, with undiagnosed rates of $50 \%-86 \%$ in an analysis of epidemiologic surveys,${ }^{44}$ figures that are supported by the fact that $<6 \%$ of adults worldwide have been told that they have COPD. ${ }^{38}$ When considered in combination, these data highlight the global issue of unreported "hidden exacerbations". It is unclear whether this is also the case in Japan.

It is estimated that $\sim 5.2$ million people aged $>40$ years live with COPD in Japan, ${ }^{45}$ although only 220,000 people were receiving treatment for COPD in 2008. ${ }^{46}$ In Japanese patients with moderate to severe COPD enrolled in a randomized study of salmeterol/fluticasone vs tiotropium, the rate of physician-diagnosed exacerbations was 0.33 /person-year compared with 1.79/person-year for an algorithm utilizing diary-detected exacerbations. ${ }^{9}$ Thus, underreporting and underdiagnosis of COPD exacerbations likely are occurring in Japan, but there is no compelling evidence that it is happening to a greater degree than any other country or region. As such, it is unlikely to be a large contributory factor to the low rates of exacerbations in Japan.

\section{Conclusion}

Reported rates of COPD exacerbations appear to be lower in Japan compared with other countries. The difference in exacerbation rate between studies appeared greater than the difference between Japan and Western countries, likely because of disparities between settings, design, and inclusion criteria. Although Japanese patients may complain less about their symptoms, this is not currently evidenced in the literature. It may be postulated that extrinsic factors such as environmental, lifestyle, and better access to health care contribute to this lower reported rate, but no evidence was found that could support or refute this hypothesis.

However, there may be differences in the diagnostic approach to COPD, specifically in relation to patients with clinical features of both COPD and asthma, which leads to a degree of diagnostic transfer and a reduction in observed COPD exacerbation incidence in Japan. There is also direct evidence that patients across the world may underreport exacerbations, even in the context of a clinical trial, and that this underreporting may also exist in Japan. Further studies are needed in cohorts that are representative of the general population, using improved tools to capture exacerbations in increasingly digitally aware patient groups. As exacerbations are associated with progression of COPD, it is important that incidences of exacerbation are correctly identified and 
reported to physicians so that patients can receive appropriate treatment. Studies in an unselected Japanese population that are comparable to studies from the rest of the world in their inclusion criteria and methods of exacerbation diagnosis are lacking and would allow for an important advancement in understanding if they were performed. Understanding the reasons why COPD exacerbation rates are lower in Japan could help clinicians to recognize and modify treatment behaviors, which may lead to improved patient outcomes in all populations.

\section{Acknowledgments}

Editorial support (in the form of literature searches, writing assistance during development of the first and subsequent drafts, assembling tables and figures, collating authors comments, grammatical editing, and referencing) was provided by Elizabeth Hutchinson, PhD, CMPP, of Fishawack Indicia Ltd, UK, funded by GlaxoSmithKline (GSK). Editorial support costs associated with preparation of this paper were funded by GSK.

\section{Author contributions}

All the authors were involved in reviewing and developing the drafts for publication and approved the final version to be submitted. TI, MN, and PJ contributed equally to the manuscript development. All authors contributed toward data analysis, drafting and revising the paper and agree to be accountable for all aspects of the work.

\section{Disclosure}

TI, AA, MJ, and PJ are employees of GlaxoSmithKline (GSK) and hold stock/shares in GSK. MN has received research grants from Nippon Boehringer Ingelheim, AstraZeneca, and Novartis Japan, as well as personal fees from Nippon Boehringer Ingelheim. The authors report no other conflicts of interest in this work.

\section{References}

1. Jones PW, Brusselle G, dal Negro RW, et al. Health-related quality of life in patients by COPD severity within primary care in Europe. Respir Med. 2011;105(1):57-66.

2. Hurst JR, Vestbo J, Anzueto A, et al. Susceptibility to exacerbation in chronic obstructive pulmonary disease. N Engl J Med. 2010;363(12): $1128-1138$

3. Global Initiative for Chronic Obstructive Lung Disease. Global Strategy for the Diagnosis, Management, and Prevention of Chronic Obstructive Pulmonary Disease (2017) Report. 2017

4. Spencer S, Jones PW; GLOBE Study Group, Group GS. Time course of recovery of health status following an infective exacerbation of chronic bronchitis. Thorax. 2003;58(7):589-593.

5. Vestbo J, Leather D, Diar Bakerly N, et al. Effectiveness of fluticasone furoate-vilanterol for COPD in clinical practice. $N$ Engl J Med. 2016; 375(13):1253-1260
6. Buhl R, Criée CP, Kardos P, et al. A year in the life of German patients with COPD: the DACCORD observational study. Int J Chron Obstruct Pulmon Dis. 2016;11:1639-1646.

7. Fukuchi Y, Fernandez L, Kuo HP, et al. Efficacy of tiotropium in COPD patients from Asia: a subgroup analysis from the UPLIFT trial. Respirology. 2011;16(5):825-835.

8. Tashkin DP, Celli B, Senn S, et al. A 4-year trial of tiotropium in chronic obstructive pulmonary disease. N Engl J Med. 2008;359(15): 1543-1554.

9. Jones P, Kato M, Fujimoto K, et al. LATE-BREAKING ABSTRACT: large differences in rate of reported and unreported COPD exacerbations in Japanese patients. Eur Respir J. 2016;48:A635.

10. Kurashima K, Takaku Y, Hoshi T, et al. Lobe-based computed tomography assessment of airway diameter, airway or vessel number, and emphysema extent in relation to the clinical outcomes of COPD. Int $J$ Chron Obstruct Pulmon Dis. 2015;10:1027-1033.

11. Matsunaga K, Hayata A, Akamatsu K, et al. Stratifying the risk of COPD exacerbation using the modified Medical Research Council scale: a multicenter cross-sectional CAP study. Respir Investig. 2015;53(2):82-85.

12. Motegi T, Jones RC, Ishii T, et al. A comparison of three multidimensional indices of COPD severity as predictors of future exacerbations. Int J Chron Obstruct Pulmon Dis. 2013;8:259-271.

13. Natori H, Kawayama T, Suetomo M, et al. Evaluation of the Modified Medical Research Council Dyspnea Scale for predicting hospitalization and exacerbation in Japanese patients with chronic obstructive pulmonary disease. Intern Med. 2016;55(1):15-24.

14. Sato M, Chubachi S, Sasaki M, et al. Impact of mild exacerbation on COPD symptoms in a Japanese cohort. Int J Chron Obstruct Pulmon Dis. 2016;11:1269-1278.

15. Suzuki M, Makita H, Ito YM, et al. Clinical features and determinants of COPD exacerbation in the Hokkaido COPD cohort study. Eur Respir J. 2014;43(5):1289-1297.

16. Takahashi T, Muro S, Tanabe N, et al. Relationship between periodontitis-related antibody and frequent exacerbations in chronic obstructive pulmonary disease. PLoS One. 2012;7(7):e40570.

17. Takayanagi S, Kawata N, Tada Y, et al. Longitudinal changes in structural abnormalities using MDCT in COPD: do the CT measurements of airway wall thickness and small pulmonary vessels change in parallel with emphysematous progression? Int J Chron Obstruct Pulmon Dis. 2017; 12:551-560.

18. Takemura M, Mitsui K, Ido M, et al. Effect of a network system for providing proper inhalation technique by community pharmacists on clinical outcomes in COPD patients. Int J Chron Obstruct Pulmon Dis. 2013;8:239-244.

19. Fukuchi Y, Tatsumi K, Inoue H, et al. Prevention of COPD exacerbation by lysozyme: a double-blind, randomized, placebo-controlled study. Int J Chron Obstruct Pulmon Dis. 2016;11:831-838.

20. Furumoto A, Ohkusa Y, Chen M, et al. Additive effect of pneumococcal vaccine and influenza vaccine on acute exacerbation in patients with chronic lung disease. Vaccine. 2008;26(33):4284-4289.

21. Sasaki T, Nakayama K, Yasuda H, et al. A randomized, single-blind study of lansoprazole for the prevention of exacerbations of chronic obstructive pulmonary disease in older patients. J Am Geriatr Soc. 2009; 57(8):1453-1457.

22. Mcgarvey L, Lee AJ, Roberts J, Gruffydd-Jones K, Mcknight E, Haughney J. Characterisation of the frequent exacerbator phenotype in COPD patients in a large UK primary care population. Respir Med. 2015;109(2):228-237.

23. Nishimura M, Makita $\mathrm{H}$, Nagai $\mathrm{K}$, et al. Annual change in pulmonary function and clinical phenotype in chronic obstructive pulmonary disease. Am J Respir Crit Care Med. 2012;185(1):44-52.

24. Gudmundsson G, Ulrik CS, Gislason T, et al. Long-term survival in patients hospitalized for chronic obstructive pulmonary disease: a prospective observational study in the Nordic countries. Int J Chron Obstruct Pulmon Dis. 2012;7:571-576.

25. Singanayagam A, Schembri S, Chalmers JD. Predictors of mortality in hospitalized adults with acute exacerbation of chronic obstructive pulmonary disease. Ann Am Thorac Soc. 2013;10(2):81-89. 
26. Development OfEC-oa. Health Policy in Japan. 2017. Available from: http://www.oecd.org/els/health-systems/Health-Policy-in-JapanMarch-2017.pdf. Accessed 15 December, 2017.

27. Development OfEC-oa. Health at a Glance 2015. 2015. Available from: https://www.oecd-ilibrary.org/social-issues-migration-health/health-ata-glance-2015_health_glance-2015-en. Accessed 15 December, 2017.

28. Nagai K, Makita H, Suzuki M, et al. Differential changes in quality of life components over 5 years in chronic obstructive pulmonary disease patients. Int J Chron Obstruct Pulmon Dis. 2015;10:745-757.

29. Wilke S, Jones PW, Müllerova H, et al. One-year change in health status and subsequent outcomes in COPD. Thorax. 2015;70(5):420-425.

30. Jones PW, Mullerova H, Agusti A, et al. Cardiovascular disease does not predict exacerbation rate or mortality in COPD. Am J Respir Crit Care Med. 2017.

31. Kida K, Motegi T, Ishii T, Hattori K. Long-term oxygen therapy in Japan: history, present status, and current problems. Pneumonol Alergol Pol. 2013;81(5):468-478.

32. Japanese Ministry of Health LaW [webpage on the Internet]. Handbook of Health and Wealth Statistics 2016. Part 1 Population an Households: Age-Adjusted Death Rates (Per 100,000 Population) by Cause of Death and Sex, by Year. 2016. Available from: http:/www.mhlw.go.jp/english/ database/db-hh/1-2.html. Accessed July 24, 2018.

33. e-STAT, Japan Sof [database on the Internet]. 2015. Available from: https://www.e-stat.go.jp/en/stat-search/files?page=1\&layout=datalis t\&tstat $=000001028897 \&$ cycle $=7 \&$ year $=20150 \&$ month $=0 \&$ tclass $1=$ $000001053058 \&$ tclass $2=000001053061 \&$ tclass $3=000001053065 \&$ result_back=1\&second2=1. Accessed January 2018 .

34. Soriano JB, Abajobir AA, Abate KH; GBD 2015 Chronic Respiratory Disease Collaborators. Global, regional, and national deaths, prevalence, disability-adjusted life years, and years lived with disability for chronic obstructive pulmonary disease and asthma, 1990-2015: a systematic analysis for the Global Burden of Disease Study 2015. Lancet Respir Med. 2017;5(9):691-706.

35. Cohen AJ, Brauer M, Burnett R, et al. Estimates and 25-year trends of the global burden of disease attributable to ambient air pollution: an analysis of data from the Global Burden of Diseases Study 2015. Lancet. 2017;389(10082):1907-1918.
36. Ministry of Health, Labour and Welfare [webpage on the Internet]. National Health and Nutrition Survey. Available from: http:// www.health-net.or.jp/tobacco/product/pd100000.html. Accessed May 2018.

37. Nanri A, Mizoue T, Shimazu T, et al. Dietary patterns and all-cause, cancer, and cardiovascular disease mortality in Japanese men and women: the Japan public health center-based prospective study. PLoS One. 2017;12(4):e0174848

38. GINA. Global Strategy for Asthma Management and Prevention. 2018. Available from: https://ginasthma.org/2018-gina-report-globalstrategy-for-asthma-management-and-prevention/. Accessed 23 July, 2017.

39. Hardin M, Silverman EK, Barr RG, et al. The clinical features of the overlap between COPD and asthma. Respir Res. 2011;12:127.

40. Suzuki M, Makita H, Konno S, et al. Asthma-like features and clinical course of chronic obstructive pulmonary disease. An Analysis from the Hokkaido COPD Cohort Study. Am J Respir Crit Care Med. 2016; 194(11):1358-1365.

41. Wilkinson TM, Donaldson GC, Hurst JR, Seemungal TA, Wedzicha JA. Early therapy improves outcomes of exacerbations of chronic obstructive pulmonary disease. Am J Respir Crit Care Med. 2004;169(12): 1298-1303.

42. Jones PW, Lamarca R, Chuecos F, et al. Characterisation and impact of reported and unreported exacerbations: results from ATTAIN. Eur Respir J. 2014;44(5):1156-1165.

43. Calverley P, Pauwels Dagger R, Löfdahl CG, et al. Relationship between respiratory symptoms and medical treatment in exacerbations of COPD. Eur Respir J. 2005;26(3):406-413.

44. Lamprecht B, Soriano JB, Studnicka M, et al. Determinants of underdiagnosis of COPD in national and international surveys. Chest. 2015;148(4):971-985.

45. Fukuchi Y, Nishimura M, Ichinose M, et al. COPD in Japan: the Nippon COPD Epidemiology study. Respirology. 2004;9(4):458-465.

46. Japanese Ministry of Health. On the Present Condition of Chronic Obstructive Pulmonary Disease (COPD). Chiyoda, Tokyo: Japanese Ministry of Health; 2008. 


\section{Supplementary materials}

Table SI Summary of key study design information from cohort studies detailing COPD exacerbation rates in Japan ${ }^{1-9}$

\begin{tabular}{|c|c|c|c|c|}
\hline Study & Study design & $\begin{array}{l}\text { Study center(s), } \\
\text { recruitment period }\end{array}$ & Inclusion criteria & Definitions of COPD exacerbation \\
\hline $\begin{array}{l}\text { Kyoto cohort } \\
\text { (Takahashi et al, } \\
2012)^{\prime}\end{array}$ & $\begin{array}{l}\text { Prospective cohort } \\
\text { study }\end{array}$ & $\begin{array}{l}\text { - Kyoto University } \\
\text { Hospital } \\
\text { - September 2006- } \\
\text { August } 2008\end{array}$ & $\begin{array}{l}\text { - Male patients with } \\
\text { COPD } \\
\text { - No exacerbation } \\
\text { history criteria }\end{array}$ & $\begin{array}{l}\text { Prospectively identified using diary cards, } \\
\text { based on an increase in any two major } \\
\text { symptoms (dyspnea, sputum purulence, and } \\
\text { sputum quantity) or an increase in one major } \\
\text { and one minor symptom (wheeze, sore } \\
\text { throat, cough, and nasal congestion/discharge) } \\
\text { for at least } 2 \text { consecutive days }\end{array}$ \\
\hline $\begin{array}{l}\text { Nippon cohort } \\
(\text { Motegi et al, } \\
2013)^{2}\end{array}$ & $\begin{array}{l}\text { Prospective cohort } \\
\text { study }\end{array}$ & $\begin{array}{l}\text { - Nippon Medical } \\
\text { School Respiratory } \\
\text { Care Clinic } \\
\text { - April-October } 2007\end{array}$ & $\begin{array}{l}\text { - Patients with COPD } \\
\text { (GOLD) } \\
\text { - } \geq 40 \text { years of age } \\
\text { - Current or ex-smokers } \\
\text { ( } \geq 20 \text { pack-years) } \\
\text { - No exacerbation } \\
\text { history criteria }\end{array}$ & $\begin{array}{l}\text { Onset or worsening of more than two } \\
\text { symptoms (dyspnea, sputum purulence or } \\
\text { volume, cough, or wheeze) for more than } \\
2 \text { consecutive days }\end{array}$ \\
\hline $\begin{array}{l}\text { Kitano cohort } \\
(\text { Takemura et al, } \\
2013)^{3}\end{array}$ & $\begin{array}{l}\text { Prospective, } \\
\text { pre-post, } \\
\text { nonequivalent } \\
\text { group study }\end{array}$ & $\begin{array}{l}\text { - Kitano Hospital } \\
\text { Medical Research } \\
\text { Institute } \\
\text { - November 2006- } \\
\text { December 2010 }\end{array}$ & $\begin{array}{l}\text { - Patients with COPD } \\
\text { (GOLD) } \\
\text { - Current or ex-smokers } \\
\text { ( } \geq 10 \text { pack-years) } \\
\text { - No change in } \\
\text { medication for } \\
3 \text { months before study } \\
\text { - No exacerbation } \\
\text { history criteria }\end{array}$ & $\begin{array}{l}\text { Symptomatic deterioration (dyspnea, cough, } \\
\text { sputum purulence/volume, or wheeze) that } \\
\text { required treatment with oral corticosteroids } \\
\text { and/or antibiotics or hospitalization }\end{array}$ \\
\hline $\begin{array}{l}\text { Hokkaido } \\
\text { cohort (Suzuki } \\
\text { et al, 20I4) }\end{array}$ & $\begin{array}{l}\text { Prospective, } \\
\text { 5-year follow-up, } \\
\text { observational study }\end{array}$ & $\begin{array}{l}\text { - Hokkaido University } \\
\text { Hospital } \\
\text { - May 2003-May } 2005\end{array}$ & $\begin{array}{l}\text { - Patients with COPD } \\
\text { (GOLD) } \\
\text { - } \geq 40 \text { years of age } \\
\text { - Current or ex-smokers } \\
\text { ( } \geq 10 \text { pack-years }) \\
\text { - No exacerbation } \\
\text { I month prior to study }\end{array}$ & $\begin{array}{l}\text { Symptom definition: worsening or new onset } \\
\text { of either two major symptoms or one major } \\
\text { and one minor symptom }\end{array}$ \\
\hline $\begin{array}{l}\text { Saitama cohort } \\
\text { (Kurashima et al, } \\
2015)^{5}\end{array}$ & $\begin{array}{l}\text { Observational } \\
\text { study conducted } \\
\text { to evaluate airway } \\
\text { structure and } \\
\text { exacerbation }\end{array}$ & $\begin{array}{l}\text { - Saitama } \\
\text { Cardiovascular and } \\
\text { Respiratory Center } \\
\text { - March-October 2013 }\end{array}$ & $\begin{array}{l}\text { - Male patients with } \\
\text { COPD } \\
\text { - No exacerbation } \\
\text { history criteria }\end{array}$ & $\begin{array}{l}\text { Respiratory exacerbations requiring treatment } \\
\text { with antibiotics and/or steroid }\end{array}$ \\
\hline $\begin{array}{l}\text { CAP study } \\
\text { (Matsunaga et al, } \\
2015)^{6}\end{array}$ & $\begin{array}{l}\text { Cross-sectional } \\
\text { study }\end{array}$ & $\begin{array}{l}\text { - Multicenter study } \\
\text { in } 15 \text { primary or } \\
\text { secondary care } \\
\text { facilities in Japan }\end{array}$ & $\begin{array}{l}\text { - Clinical diagnosis of } \\
\text { COPD } \\
\text { - } 40-95 \text { years of age } \\
\text { - No exacerbation in the } \\
4 \text { weeks prior to the } \\
\text { survey }\end{array}$ & $\begin{array}{l}\text { An acute event characterized by a worsening } \\
\text { of respiratory symptoms that was beyond } \\
\text { normal day-to-day variations and led to a } \\
\text { change in medication (identified using medical } \\
\text { records) }\end{array}$ \\
\hline $\begin{array}{l}\text { Kurume cohort } \\
\text { (Natori et al, } \\
2016)^{7}\end{array}$ & $\begin{array}{l}\text { A } 52 \text {-week } \\
\text { prospective } \\
\text { observational study }\end{array}$ & $\begin{array}{l}\text { - Kurume University } \\
\text { and Chikugo City } \\
\text { Hospital }\end{array}$ & $\begin{array}{l}\text { - Patients with COPD } \\
\text { (GOLD) } \\
\text { - No exacerbation } \\
4 \text { weeks prior to study } \\
\text { entry }\end{array}$ & $\begin{array}{l}\text { Increased cough and sputum production, } \\
\text { a change in sputum color, and worsening } \\
\text { of dyspnea from a stable state and beyond } \\
\text { normal day-to-day variations }\end{array}$ \\
\hline
\end{tabular}

(Continued) 
Table SI (Continued)

\begin{tabular}{|c|c|c|c|c|}
\hline Study & Study design & $\begin{array}{l}\text { Study center(s), } \\
\text { recruitment period }\end{array}$ & Inclusion criteria & Definitions of COPD exacerbation \\
\hline $\begin{array}{l}\text { Keio cohort } \\
\text { (Sato et al, } \\
2016)^{8}\end{array}$ & $\begin{array}{l}\text { Prospective } \\
\text { observational } \\
\text { cohort study }\end{array}$ & $\begin{array}{l}\text { - Keio University and } \\
\text { affiliated Hospitals } \\
\text { - April 2010- } \\
\text { December } 2012\end{array}$ & $\begin{array}{l}\text { - Patients with COPD } \\
\text { (spirometry) } \\
\text { - No exacerbation for } \\
\geq \text { I month prior to } \\
\text { enrollment }\end{array}$ & $\begin{array}{l}\text { Moderate COPD: requirement for treatment } \\
\text { with systemic corticosteroids/antibiotics/both. } \\
\text { Severe COPD: requiring hospitalization and } \\
\text { emergency admission for }>24 \text { hours }\end{array}$ \\
\hline $\begin{array}{l}\text { Chiba cohort } \\
\text { (Takayanagi } \\
\text { et al, 2017) }\end{array}$ & $\begin{array}{l}\text { Prospective, } \\
2 \text {-year, } \\
\text { observational study }\end{array}$ & $\begin{array}{l}\text { - Chiba University } \\
\text { Hospital } \\
\text { - May 2012-July 20I4 }\end{array}$ & $\begin{array}{l}\text { - Patients with COPD } \\
\text { (ATS/ERS) } \\
\text { - Current or ex-smokers } \\
\text { - No exacerbation } \\
\text { history criteria }\end{array}$ & $\begin{array}{l}\text { Deterioration of COPD that requires } \\
\text { antibiotics and/or systemic steroid use }\end{array}$ \\
\hline
\end{tabular}

Note: All data reported as mean \pm SD unless otherwise stated.

Abbreviations: ATS/ERS, American Thoracic Society/European Respiratory Society recommendations; GOLD, Global initiative for chronic Obstructive Lung Disease.

Table S2 Summary of key study design information from RCTs detailing COPD exacerbation rates in Japan ${ }^{10-14}$

\begin{tabular}{|c|c|c|c|c|}
\hline Study & Study characteristics & $\begin{array}{l}\text { Study center(s), } \\
\text { recruitment period }\end{array}$ & Inclusion criteria & $\begin{array}{l}\text { Definitions of COPD } \\
\text { exacerbation }\end{array}$ \\
\hline $\begin{array}{l}\text { Furumoto } \\
\text { et al } \\
(2008)^{10}\end{array}$ & $\begin{array}{l}\text { Open-label, randomized, } \\
\text { controlled study in patients } \\
\text { with chronic lung disease }\end{array}$ & $\begin{array}{l}\text { - Thirteen hospitals in } \\
\text { Kyushu and Okinawa } \\
\text { district } \\
\text { - November 200I- } \\
\text { April } 2002\end{array}$ & $\begin{array}{l}\text { - Patients with chronic lung } \\
\text { disease including COPD, } \\
\text { sequelae of pulmonary } \\
\text { tuberculosis } \\
\text { - Previous exacerbations }\end{array}$ & $\begin{array}{l}\text { Two of the three defined respiratory } \\
\text { symptoms existed or when one of } \\
\text { these and one additional symptom, } \\
\text { such as a fever without any other } \\
\text { causes or increased cough, was } \\
\text { present }\end{array}$ \\
\hline $\begin{array}{l}\text { Sasaki et al } \\
(2009)^{\prime \prime}\end{array}$ & $\begin{array}{l}\text { Randomized, I2-month, } \\
\text { observer-blind, controlled } \\
\text { trial }\end{array}$ & $\begin{array}{l}\text { - One University Hospital } \\
\text { and three city hospitals in } \\
\text { Miyagi prefecture } \\
\text { - October 2005-March } 2007\end{array}$ & $\begin{array}{l}\text { - Patients with COPD } \\
\text { - No exacerbation criteria } \\
\text { for inclusion or exclusion }\end{array}$ & $\begin{array}{l}\text { Acute and sustained worsening of } \\
\text { COPD symptoms requiring changes } \\
\text { to regular treatment }\end{array}$ \\
\hline $\begin{array}{l}\text { Fukuchi et al } \\
(20 \mathrm{II})^{12}\end{array}$ & $\begin{array}{l}\text { Randomized, double } \\
\text { blinded, placebo controlled } \\
\text { study (UPLIFT) }\end{array}$ & - Multicenter study & $\begin{array}{l}\text { - Patients with COPD } \\
\text { - Age } \geq 40 \text { years } \\
\text { - Post-FEV, } \% \text { pred: } \leq 70 \% \\
\text { - Post-FEV,/FVC: } \leq 70 \% \\
\text { - Smoking history } \geq 10 \\
\text { pack-years } \\
\text { - No exacerbation } 4 \text { weeks } \\
\text { before screening }\end{array}$ & $\begin{array}{l}\text { An increase in or the new onset of } \\
\text { more than one respiratory symptom } \\
\text { (cough, sputum, sputum purulence, } \\
\text { wheezing, or dyspnea) lasting } 3 \text { days } \\
\text { or more and requiring treatment } \\
\text { with an antibiotic or a systemic } \\
\text { corticosteroid }\end{array}$ \\
\hline $\begin{array}{l}\text { Fukuchi et al } \\
(2016)^{13}\end{array}$ & $\begin{array}{l}\text { Randomized, double-blind, } \\
\text { placebo-controlled parallel } \\
\text { trial }\end{array}$ & $\begin{array}{l}\text { - Multicenter study across } \\
47 \text { medical institutions in } \\
\text { Japan } \\
\text { - August 2012-January } 2015\end{array}$ & $\begin{array}{l}\text { - Patients with COPD } \\
\text { - Age: } \geq 20 \text { to }<85 \text { years } \\
\text { - Post-FEV,\% pred: }<80 \% \\
\text { - Post-FEV,/FVC: }<70 \% \\
\text { - } \geq 1 \text { exacerbations in the } \\
\text { previous year } \\
\text { - No exacerbation } \\
7 \text { days prior to drug } \\
\text { administration }\end{array}$ & $\begin{array}{l}\text { Worsening of more than one } \\
\text { symptom of COPD (cough, sputum } \\
\text { volume, purulent sputum, or } \\
\text { breathlessness) leading to a change } \\
\text { in medication }\end{array}$ \\
\hline $\begin{array}{l}\text { Jones et al } \\
(2016)^{14}\end{array}$ & $\begin{array}{l}\text { Randomized, controlled, } \\
\text { 24-week study assessing } \\
\text { exacerbations using } \\
\text { EXACT and physician } \\
\text { diagnosis (COSMOS-J } \\
\text { study) }\end{array}$ & $\begin{array}{l}\text { - Multicenter study } \\
\text { - February 2013- } \\
\text { September 2015 }\end{array}$ & $\begin{array}{l}\text { - Patients with COPD } \\
\text { (GOLD) } \\
\text { - Age } 40-80 \text { years } \\
\text { - Post-FEV,/FVC: }<70 \% \\
\text { - Current or ex-smokers } \\
\text { (>10 pack-years) }\end{array}$ & $\begin{array}{l}\text { Physician diagnosis of exacerbation } \\
\text { and evaluation of EXACT diary }\end{array}$ \\
\hline
\end{tabular}

Note: All data reported as mean \pm SD unless otherwise stated.

Abbreviations: EXACT, Exacerbations of Chronic Pulmonary Disease Tool; GOLD, Global initiative for chronic Obstructive Lung Disease; pred, predicted. 


\section{References}

1. Takahashi T, Muro S, Tanabe N, et al. Relationship between periodontitisrelated antibody and frequent exacerbations in chronic obstructive pulmonary disease. PLoS One. 2012;7(7):e40570.

2. Motegi T, Jones RC, Ishii T, et al. A comparison of three multidimensional indices of COPD severity as predictors of future exacerbations. Int J Chron Obstruct Pulmon Dis. 2013;8:259-271.

3. Takemura M, Mitsui K, Ido M, et al. Effect of a network system for providing proper inhalation technique by community pharmacists on clinical outcomes in COPD patients. Int J Chron Obstruct Pulmon Dis. 2013;8:239-244.

4. Suzuki M, Makita H, Ito YM, et al. Clinical features and determinants of COPD exacerbation in the Hokkaido COPD cohort study. Eur Respir J. 2014;43(5):1289-1297.

5. Kurashima K, Takaku Y, Hoshi T, et al. Lobe-based computed tomography assessment of airway diameter, airway or vessel number, and emphysema extent in relation to the clinical outcomes of COPD. Int $J$ Chron Obstruct Pulmon Dis. 2015;10:1027-1033.

6. Matsunaga K, Hayata A, Akamatsu K, et al. Stratifying the risk of COPD exacerbation using the modified Medical Research Council scale: a multicenter cross-sectional CAP study. Respir Investig. 2015;53(2):82-85.

7. Natori H, Kawayama T, Suetomo M, et al. Evaluation of the Modified Medical Research Council Dyspnea Scale for predicting hospitalization and exacerbation in Japanese patients with chronic obstructive pulmonary disease. Intern Med. 2016;55(1):15-24.
8. Sato M, Chubachi S, Sasaki M, et al. Impact of mild exacerbation on COPD symptoms in a Japanese cohort. Int J Chron Obstruct Pulmon Dis. 2016;11:1269-1278.

9. Takayanagi S, Kawata N, Tada Y, et al. Longitudinal changes in structural abnormalities using MDCT in COPD: do the CT measurements of airway wall thickness and small pulmonary vessels change in parallel with emphysematous progression? Int J Chron Obstruct Pulmon Dis. 2017; $12: 551-560$.

10. Furumoto A, Ohkusa Y, Chen M, et al. Additive effect of pneumococcal vaccine and influenza vaccine on acute exacerbation in patients with chronic lung disease. Vaccine. 2008;26(33):4284-4289.

11. Sasaki T, Nakayama K, Yasuda H, et al. A randomized, single-blind study of lansoprazole for the prevention of exacerbations of chronic obstructive pulmonary disease in older patients. J Am Geriatr Soc. 2009; 57(8):1453-1457.

12. Fukuchi Y, Fernandez L, Kuo HP, et al. Efficacy of tiotropium in COPD patients from Asia: a subgroup analysis from the UPLIFT trial. Respirology. 2011;16(5):825-835.

13. Fukuchi Y, Tatsumi K, Inoue H, et al. Prevention of COPD exacerbation by lysozyme: a double-blind, randomized, placebo-controlled study. Int J Chron Obstruct Pulmon Dis. 2016;11:831-838.

14. Jones P, Kato M, Fujimoto K, et al. LATE-BREAKING ABSTRACT: large differences in rate of reported and unreported COPD exacerbations in Japanese patients. Eur Respir J. 2016;48:A635.
International Journal of COPD

\section{Publish your work in this journal}

The International Journal of COPD is an international, peer-reviewed journal of therapeutics and pharmacology focusing on concise rapid reporting of clinical studies and reviews in COPD. Special focus is given to the pathophysiological processes underlying the disease, intervention programs, patient focused education, and self management protocols.

\section{Dovepress}

This journal is indexed on PubMed Central, MedLine and CAS. The manuscript management system is completely online and includes a very quick and fair peer-review system, which is all easy to use. Visit http://www.dovepress.com/testimonials.php to read real quotes from published authors. 